U. S. Department of the Interior

U. S. Geological Survey

\title{
TOTAL PETROLEUM SYSTEMS OF THE NORTHWEST SHELF, AUSTRALIA: \\ THE DINGO-MUNGAROO/BARROW AND \\ THE LOCKER-MUNGAROO/BARROW
}

by

Michele G. Bishop ${ }^{1}$

Open-File Report 99-50-E

This report is preliminary and has not been reviewed for conformity with the U. S. Geological Survey editorial standards or with the North American Stratigraphic Code. Any use of trade names is for descriptive purposes only and does not imply endorsements by the U. S. government.

${ }^{1}$ Consultant, Wyoming PG-783, contracted to U. S. Geological Survey, Denver, Colorado 


\section{FOREWORD}

This report was prepared as part of the World Energy Project of the U.S. Geological Survey. In the project, the world was divided into 8 regions and 937 geologic provinces. The provinces have been ranked according to the discovered oil and gas volumes within each (Klett and others, 1997). Then, 76 "priority" provinces (exclusive of the U.S. and chosen for their high ranking) and 26 "boutique" provinces (exclusive of the U.S. and chosen for their anticipated petroleum richness or special regional economic importance) were selected for appraisal of oil and gas resources. The petroleum geology of these priority and boutique provinces is described in this series of reports.

The purpose of this effort is to aid in assessing the quantities of oil, gas, and natural gas liquids that have the potential to be added to reserves within the next 30 years. These volumes either reside in undiscovered fields whose sizes exceed the stated minimumfield-size cutoff value for the assessment unit (variable, but must be at least 1 million barrels of oil equivalent) or occur as reserve growth of fields already discovered.

The total petroleum system constitutes the basic geologic unit of the oil and gas assessment. The total petroleum system includes all genetically related petroleum that occurs in shows and accumulations (discovered and undiscovered) that has been generated by a pod or by closely related pods of mature source rock and which exists within a limited mappable geologic space, together with the essential mappable geologic elements (source, reservoir, seal, and overburden rocks) that control the fundamental 
processes of generation, expulsion, migration, entrapment, and preservation of petroleum. The minimum petroleum system is that part of a total petroleum system encompassing discovered shows and accumulations together with the geologic space in which the various essential elements have been proved by these discoveries.

An assessment unit is a mappable part of a total petroleum system in which discovered and undiscovered fields constitute a single relatively homogenous population such that the chosen methodology of resource assessment based on estimation of the number and sizes of undiscovered fields is applicable. A total petroleum system might equate to a single assessment unit. If necessary, a total petroleum system may be subdivided into two or more assessment units such that each assessment unit is sufficiently homogeneous in terms of geology, exploration considerations, and risk to assess individually.

A graphical depiction of the elements of the a total petroleum system is provided in the form of an event chart that shows the time of deposition of essential rock units; the time processes, such as trap formation, necessary to the accumulation of hydrocarbons took place; the critical moment in the total petroleum system; and the preservation time, if any. A numeric code identifies each region, province, total petroleum system, and assessment unit; these codes are uniform throughout the project and will identify the same item in any of the publications. The code is as follows:

\section{Example}

Region, single digit 
Province, three digits to the right of region code

Total Petroleum System, two digits to the right of province code

Assessment unit, two digits to the right of petroleum system code

31620504

The codes for the regions and provinces are listed in Klett and others, 1997.

Oil and gas reserves quoted in this report are derived from Petroleum Exploration and Production database (Petroconsultants, 1996) and other area reports from Petroconsultants, Inc., unless otherwise noted.

Fields, for the purpose of this report, include producing fields, discoveries (suspended and abandoned) and shows as defined by PetroConsultants (1996) and may consist of a single well with no production.

Figure(s) in this report that show boundaries of the total petroleum system(s), assessment units, and pods of active source rocks were compiled using geographic information system (GIS) software. Political boundaries and cartographic representations were taken, with permission, from Environmental Systems Research Institute's ArcWorld 1:3 million digital coverage (1992), have no political significance, and are displayed for general reference only. Oil and gas field centerpoints, shown on this(these) figure(s), are reproduced, with permission, from Petroconsultants, 1996.

\section{REFERENCES}


Environmental Systems Research Institute Inc., 1992, ArcWorld 1:3M digital database: Environmental Systems Research Institute, Inc. (ESRI), available from ESRI, Redlands, CA, scale: 1:3,000,000.

Klett, T.R., Ahlbrandt, T.A., Schmoker, J.W., and Dolton, G.L., 1997, Ranking of the world's oil and gas provinces by known petroleum volumes: U.S. Geological Survey Open-File Report 97-463, one CD-ROM.

Petroconsultants, 1996, Petroleum Exploration and Production Database :

Petroconsultants, Inc., P.O. Box 740619, 6600 Sands Point Drive, Houston TX

77274-0619, USA or Petroconsultants, Inc., P.O. Box 152, 24 Chemin de la Mairie, 1258 Perly, Geneva, 


\section{ABSTRACT}

The Northwest Shelf Province (U.S.G.S. \#3948) of Australia contains two important hydrocarbon source-rock intervals and numerous high quality reservoir intervals. These are grouped into two petroleum systems, Dingo-Mungaroo/Barrow and Locker-Mungaroo/Barrow, where the Triassic Mungaroo Formation and the Early Cretaceous Barrow Group serve as the major reservoir rocks for the Jurassic Dingo Claystone and Triassic Locker Shale source rocks. The primary source rock, Dingo Claystone, was deposited in restricted marine conditions during the Jurassic subsidence of a regional sub-basin trend. The secondary source rock, Locker Shale, was deposited in terrestrially-influenced, continental seaway conditions during the Early Triassic at the beginning of the breakup of Pangea. These systems share potential reservoir rocks of deep-water, proximal and distal deltaic, marginal marine, and alluvial origins, ranging in age from Late Triassic through Cretaceous. Interformational seals and the regional seal, Muderong Shale, along with structural and stratigraphic traps account for the many types of hydrocarbon accumulations in this province. In 1995, the Northwest Shelf produced 42\% of the hydrocarbon liquids in Australia, and in 1996 surpassed the Australian Bass Straits production, with 275,000 barrels per day (bpd) average. This region is the major producing province of Australia. Known reserves as of 1995 are estimated at 11.6 billion of barrels of oil equivalent (BBOE)(Klett and others, 1997) . Although exploration has been conducted since 1955, many types of prospects have not been targeted and major reserves continue to be discovered. 


\section{INTRODUCTION}

There are two important Total Petroleum Systems (TPS) in the Northwest Shelf Province 3948, Australia (Fig. 1). The primary TPS, the Dingo-Mungaroo/Barrow 394801, is defined by the Jurassic Dingo Claystone as the hydrocarbon source rock, and the Triassic Mungaroo Formation, Jurassic rocks, and the Cretaceous Barrow Group as reservoir rocks. The second important TPS, the Locker-Mungaroo/Barrow 394802, includes the Triassic Locker Shale source rock and the Triassic Mungaroo Formation and the Cretaceous Barrow Group as reservoir rocks. These two petroleum systems contain one assessment unit each for the purposes of predicting hydrocarbon resources.

Other minor petroleum systems are possible. For example, Permian age organicrich rocks underlying the Locker Shale may contribute hydrocarbons to the LockerMungaroo/Barrow system. Coals and marginal marine rocks of the Mungaroo Formation overlying the Locker Shale could also be source rocks. Hydrocarbons derived from Paleozoic intervals may be present in the North West Cape and structural terraces such as the Enderby and Candance terraces (Fig. 2).

\section{PROVINCE GEOLOGY}

The Northwest Shelf Province 3948, encompasses an onshore and offshore area from North West Cape to near Broome in the northern part of Western Australia (Fig. 1). From southwest to northeast the larger divisions of the Province are: Northern Carnarvon Basin with the Exmouth Plateau, Kangaroo trough, Exmouth sub-basin, Peedamullah shelf, Lambert shelf, Candace terrace, Enderby terrace, Barrow sub-basin, Dampier sub- 

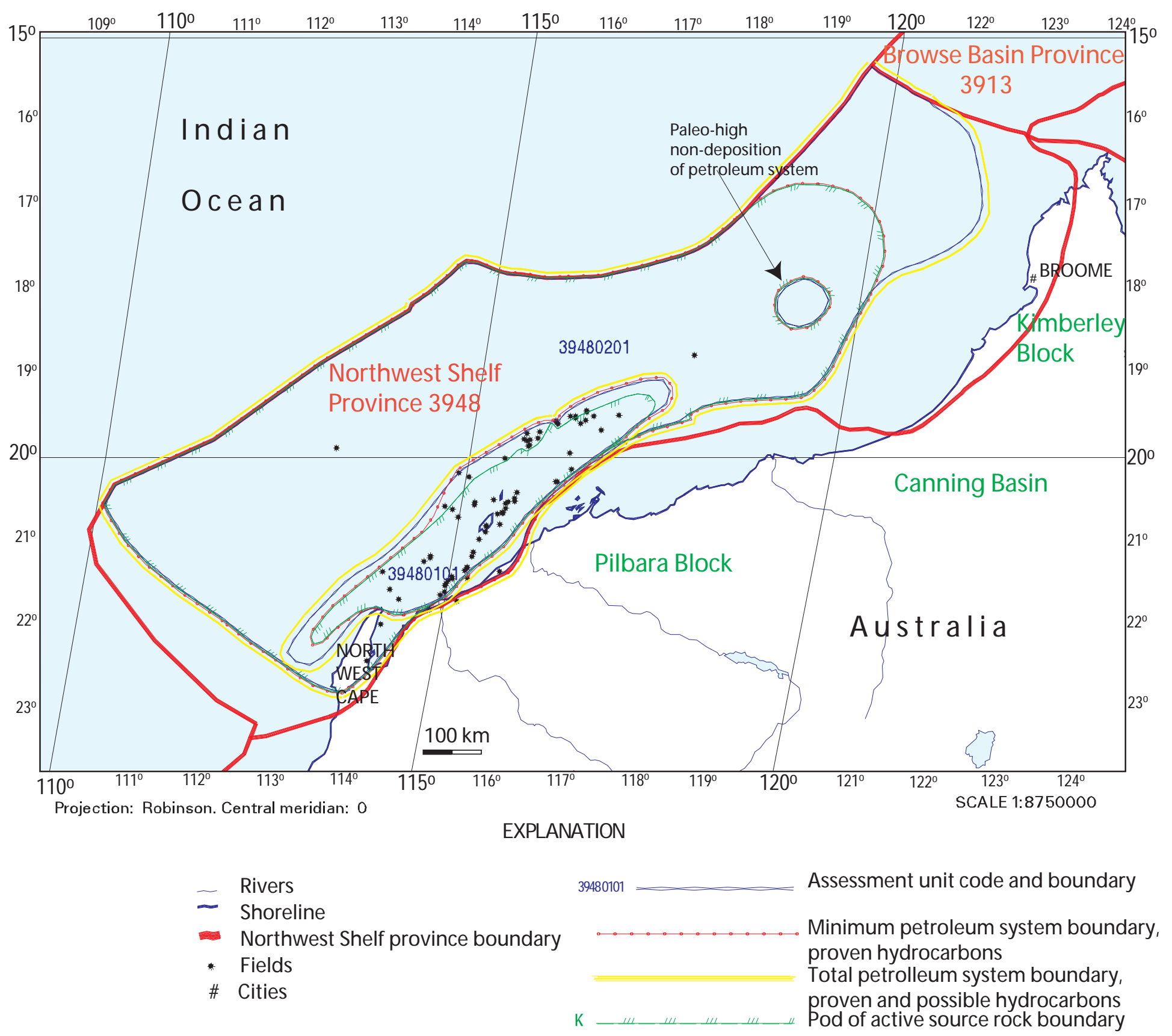

Figure 1. Index map of USGS Province 3948 Northwest Shelf,Australia. Shown are two petroleum systems (394801, the Dingo-Mungaroo, Barrow; 39480, the Locker-Mungaroo, Barrow) each with one assessment unit (39480101, 39480201). 


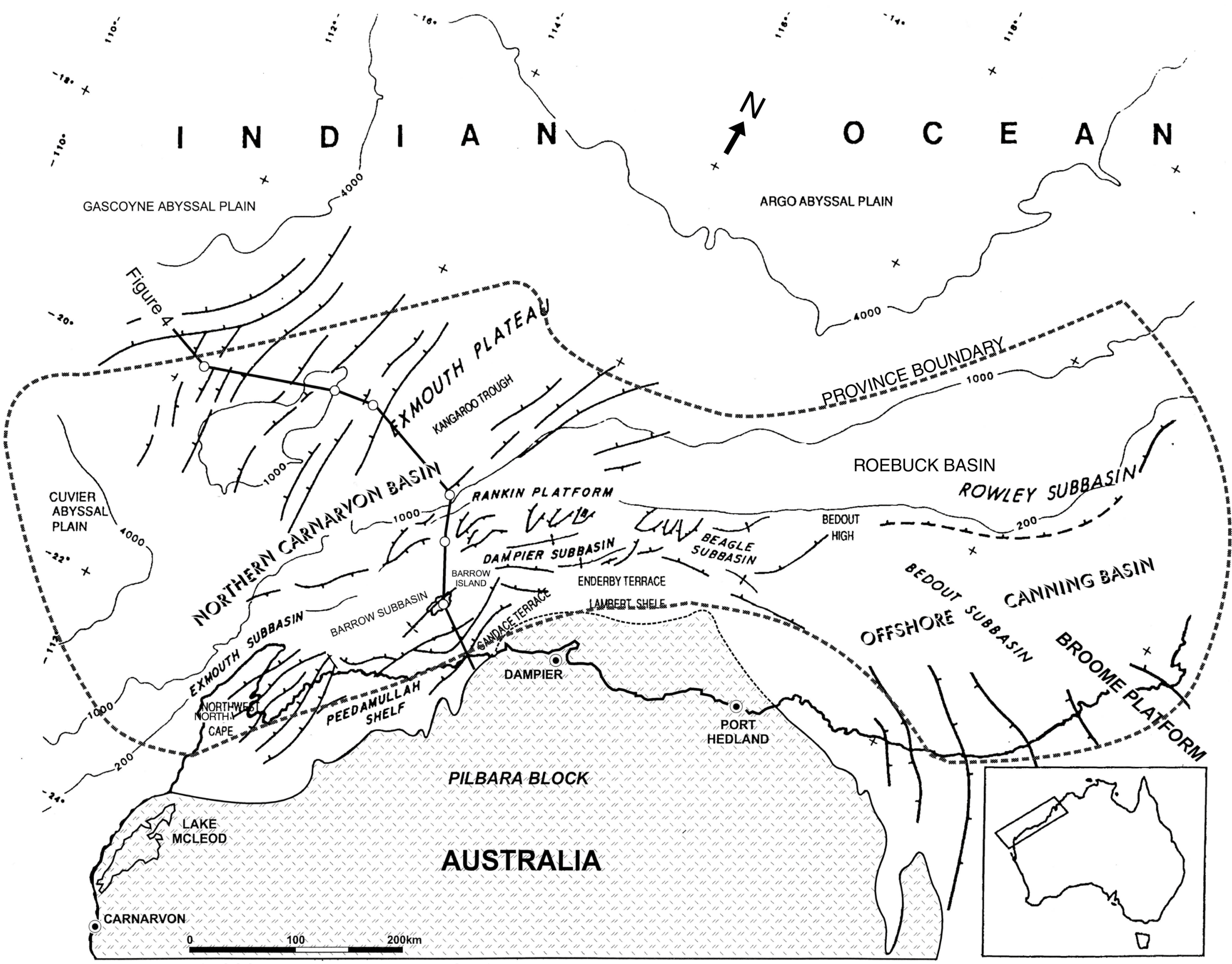

Figure 2. Index map of USGS Province 3948 Northwest Shelf, Australia. Major structural elements, basins, plateaus, bathymetric contours in meters, and geograhical features are shown. Modified from Parry and Smith, 1988. 
basin, Beagle sub-basin, and the Rankin Platform (Fig. 2). Also included is the Roebuck Basin divided into the Bedout sub-basin, Bedout high, and the Rowley sub-basin all west of offshore or northern Canning Basin. Ridges and troughs within the sub-basins are controlled by underlying fault-block trends. Oceanwards of the Roebuck Basin and northeast of the Exmouth Plateau is Jurassic age oceanic crust of the Argo Abyssal Plain, and to the northwest and southwest of the Exmouth Plateau, Cretaceous age oceanic crust of the Gascoyne and Cuvier abyssal plains.

The Northwest Shelf Province lies in the onshore and offshore jurisdiction of Western Australia. A natural gas pipeline, south to Perth, has been in operation from Barrow Island and adjacent fields since 1984. Offshore islands are used for storage and transmission facilities. This pipeline has been extended to include new fields as they have been developed. Many large discoveries have not as yet been produced and are shut-in or abandoned due to market conditions or technology costs.

The Northwest Shelf has been involved in several continental rifting periods characterized by shifts in the location of rifts, failure of rifts, and changes in the direction of stress. These rifts are associated with Cambrian age separation of Australia from Chinese continental blocks forming the paleo-Tethys Ocean (Baillie and others, 1994), and Carboniferous to Permian age separation of China-Burma-Malay-Sumatra continental blocks forming the neo-Tethys Ocean (Veevers, 1974).

Paleozoic failed rifts, with a present-day northwest-southeast trend, including the Canning Basin (intersecting the northern end of this province), Joseph Bonaparte Gulf (northeast of this province), and Southern Carnarvon Basin (southwest of this province), have continued to influence structural development. These failed rifts were connected by 
a vast and persistent sag basin, or continental seaway, roughly along the modern Australian northwest shelf. Land offshore of the modern continent and the continent itself shed clastics into the seaway from both sides. Marine to nonmarine sediment has accumulated since the Carboniferous to a thickness of 12-15 km (Stagg and Colwell, 1994). Two reasonably stable basement cratons, the Pilbara Block south of the Canning Basin and the Kimberley Block north of the Canning Basin, are currently exposed onshore and anchor the modern continental margin (Fig. 1).

Carboniferous and Permian sediments are known from penetrations onshore, nearshore, and from the Exmouth Plateau, and are inferred from seismic data (Bentley, 1988; AGSO North West Shelf Study Group, 1994). These sediments record the waning Gondwana glaciation as glacial drift and tillites of the Lyons Group. Shelf carbonates and siltstones were deposited during a subsequent sea level rise, followed by fluvial, deltaic, and shoreface deposits of the Wooramel Group. Another marine transgression is represented by shales, siltstones, and sandstones of the Byro Group (Hocking, 1988). The Late Permian Kennedy Group consists of barrier bar sandstones interbedded with coals.

The persistent continental seaway accumulated Triassic sediments beginning with deposition of the regional Locker Shale source rock over a transgressive sandstone (Fig. 3). The overlying Mungaroo Formation deltas and shorelines prograded from the Pilbara highlands area across the seaway perpendicular to the modern coast. Interpretations of deep-seismic profiles acquired since 1990 (AGSO North West Shelf Study Group, 1994) show that the entire Triassic section, which is approximately $4 \mathrm{~km}$ at the Exmouth Plateau, is thin where it overlies the offshore portions of the Canning Basin. The Triassic 


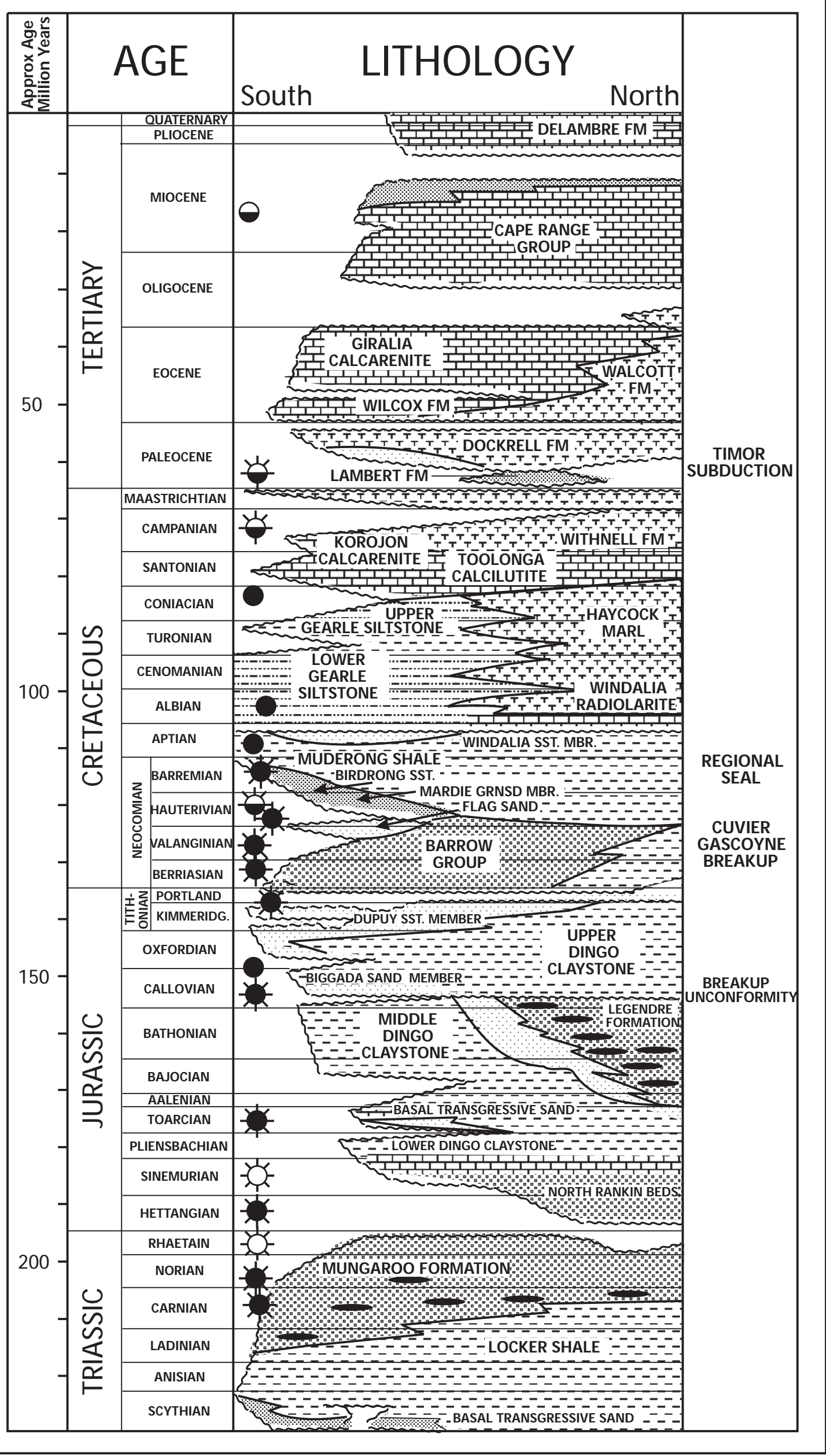

Figure 3. Stratigraphy of the Barrow-Dampier and Rankin Trend with discoveries and shows. After Butcher, 1989 
section thickens, to approximately $7 \mathrm{~km}$, in a wedge shape oceanward of the Bedout high. The section is abruptly cut off at the Argo Abyssal Plain, the missing portion of the basin having drifted away. Uniformly thick Triassic rocks to the south are similarly truncated along the outer edge of the Exmouth Plateau where the Gascoyne Abyssal Plain formed by breakup of the Triassic seaway (Fig.4). Triassic strata are inferred to underlie the Barrow and Dampier sub-basins and have been encountered in wells on the inner structural terraces (Fig. 2)(Gorter, 1994; Bentley, 1988). Triassic movement of faults that define the inner structural terraces is evidenced by thickening of the Locker Shale across the faults and deep lowstand-canyon erosion of the Locker Shale on some terraces (Gorter, 1994).

The close of the Triassic is represented by a regional and angular unconformity involving faulting and tilting of fault blocks across the Exmouth Plateau. At this time the Northwest Shelf divided into several tectonic provinces that influenced subsequent depositional events and provided for the generation and accumulation of hydrocarbons.

During Jurassic time, a string of en echelon, faulted sub-basins formed a subbasin trend along the inner portions of the continental seaway separating the Exmouth Plateau, Rankin Platform trend on the west from the complex shelf margin formed by fault-block terraces that edge the craton to the east (Fig. 2). The down dropping and subsidence of these sub-basins provided space for deposition of the thick, Jurassic Dingo Claystone in three sequences, lower, middle and upper (Fig.3). This sub-basin trend was 500-1000 m deep and marine circulation was restricted by emergent land offshore and at the north end of the trend. Subsidence in this trend was greatest in the Barrow sub-basin and decreased northward to where continental deposition and erosion intermittently 


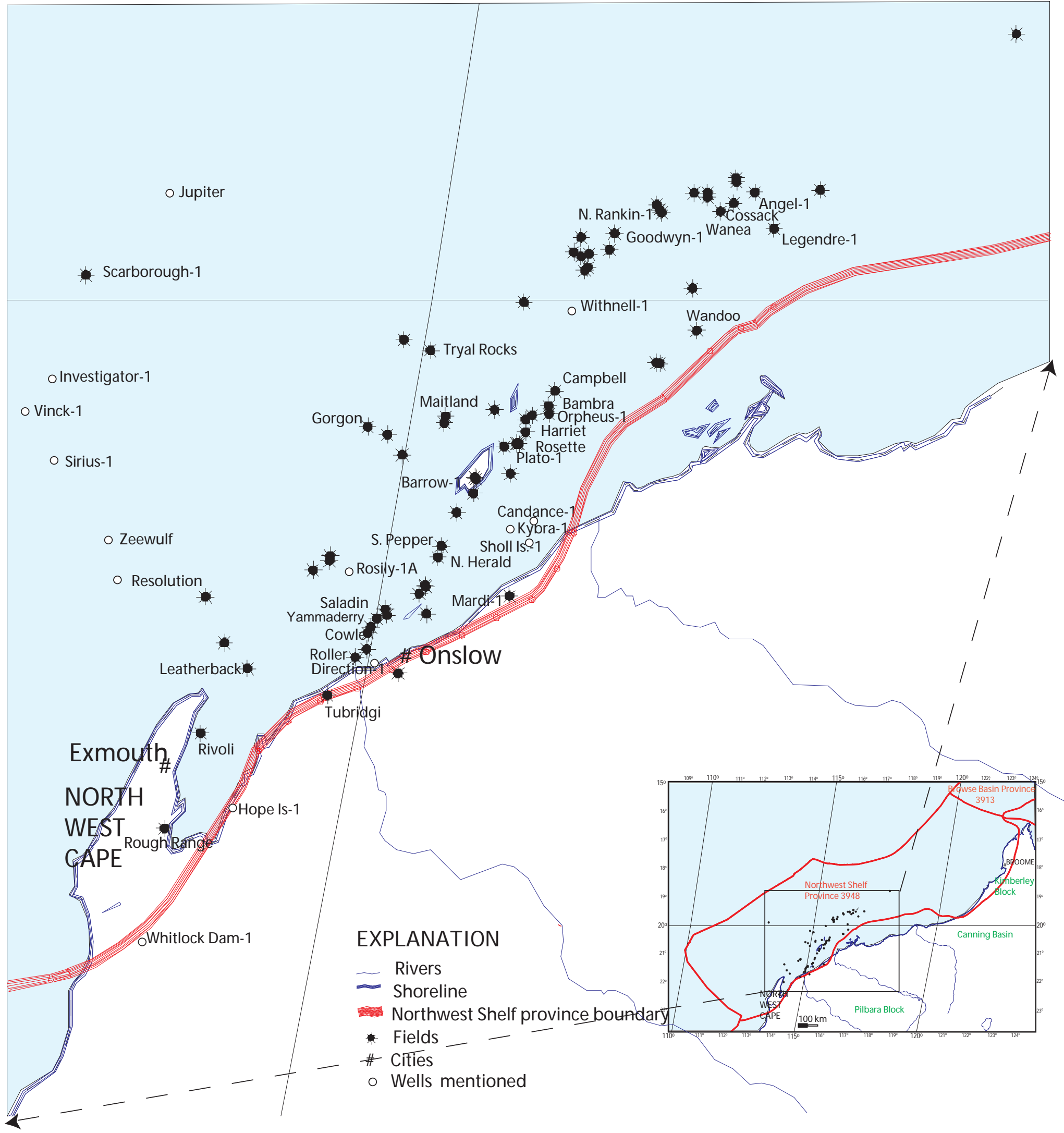

Figure 4. Detail of index map of USGS Province 3948 Northwest Shelf, Australia. Fields are shown and wells and fields mentioned in the text are labeled. 
characterized the Roebuck Basin. Transgressive sands, regressive deltas, and deep-water fans were deposited in the sub-basins from erosion of the continent and exposed portions of the Northwest Shelf.

Jurassic age shale was intermittently deposited in troughs and lows formed by tilted fault blocks on the Exmouth Plateau when the plateau was partially submerged (Stagg and Colwell, 1994). As subsidence in the sub-basins slowed, deposition of the Upper Dingo Claystone overtopped most of the Exmouth Plateau as a thin veneer.

Another major unconformity, due to Tithonian tectonic fault reactivation and uplift of the Exmouth Plateau, is overlain by the Early Cretaceous, 1500-2000 m thick (Exon and von Rad, 1994) deltaic Barrow Group (Fig.3). The Barrow Group contains several producing reservoir members from delta bottomset and topset sandstones and from delta-front and deep-water deposits. Detailed sequence stratigraphy indicates two major depocenters, an older one to the northwest over the Exmouth Plateau and a younger one to the southeast over the sub-basin trend (Ross and Vail, 1994). The Indian plate to the southwest was the source area for clastics that prograded along the sub-basin trend and across the Exmouth Plateau, filling in remaining relief. The delta front of the delta complex was roughly perpendicular to the modern shoreline and prograded as far east as northern Barrow Island. The end of Barrow deposition marks Late Neocomian movement of the Indian plate away from the west coast of Australia. The subsequent Late Valanginian Muderong Shale contains the transgressive Mardie Greensand and Birdrong Sandstone Members, which are important reservoirs (Fig.3). The Muderong Shale records a rise and stillstand in sea level and the restoration of a coast-parallel sequence trend and also acts as a regional seal. 
Carbonate deposition has dominated the Australian northwest continental margin since formation of the Aptian-Albian unconformity (Fig. 3). Up to $3 \mathrm{~km}$ of postunconformity carbonate strata has been deposited. Several hydrocarbon accumulations in this interval were fed by faults cutting the regional seal. Tectonic movements of the region in Late Cretaceous through Miocene time were relatively minor.

\section{Exploration History}

Oil was discovered onshore at Rough Range field in 1955 on the North West Cape in the deltaic Birdrong Sandstone (Fig. 4)(Table 1). Subsequent surveys and mapping by the Geological Survey of Western Australia were extended offshore to include Barrow Island and the Dampier Archipelago. Exploration activity increased in the early 1960's and Barrow-1, drilled in 1963, was the first oil discovery in the Northwest Shelf Province. Barrow-1 tested oil, gas, and condensate from Upper Albian to Callovian rocks of a faulted anticline. Detailed water-depth maps were used to target ridges offshore. In 1967 the Ashmore-1 was drilled $350 \mathrm{~km}$ from the coast and was dry. Legendre-1, $180 \mathrm{~km}$ NE of Barrow Island, found noncommercial oil in Lower Cretaceous deltaic deposits of the Neocomian Barrow Group. North Rankin-1, drilled in 1971, was a giant gas and condensate discovery in Late Triassic, marginal-marine Mungaroo Formation. Subsequently, Angel field was discovered, finding gas and condensate with oil shows in a Late Jurassic marine interval. In 1972, Goodwyn-1 discovered gas and condensate in a Lower Jurassic channel fill and oil in an Upper Triassic fluvial interval. This encouraging start in a remote location with no infrastructure, technical challenges, and high finding costs was dampened in 1972 when the Labor Party won the Federal election and the new Minister for Energy declared an embargo on hydrocarbon 


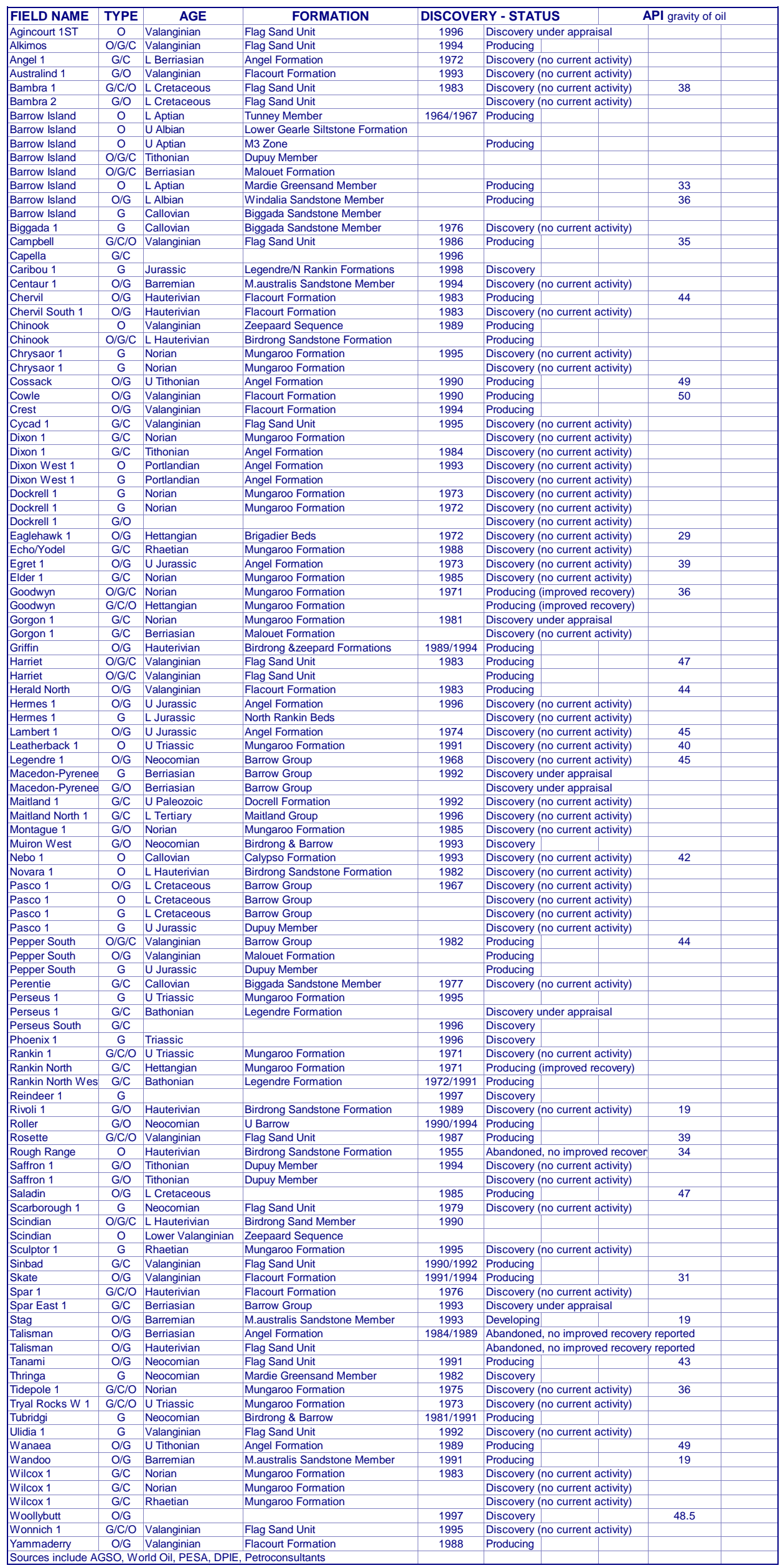

TABLE I

Significant discoveries, NW Shelf, Australia

Sources include AGSO, World Oil, PESA, DPIE, Petroconsultants 
exports. The effect was to slow exploration in Australia for several years (Purcell and Purcell, 1988).

Excitement again was high in 1979 for the Northwest Shelf Province when Scarborough-1 found an estimated 15 trillion cubic feet of gas (TCFG) accumulation in Cretaceous deep-water sands on the Exmouth Plateau in 912 meters of water. From 1979 to 1984 , five gas fields, four oil fields, and three oil and gas fields were discovered. These include discoveries in Cretaceous marginal marine and deltaic strata, Triassic fluvial strata, and Cretaceous deep-water strata. Gas production commenced in 1984, Harriet field came online in 1986, and North Herald and South Pepper fields in 1987.

\section{PETROLEUM OCCURRENCE}

Mature source rocks of the Dingo-Mungaroo/Barrow 394801 TPS are located in the Exmouth, Barrow, and Dampier sub-basins (Fig. 2). Accumulations of this primary system occur 1) within the sub-basin trend, 2) directly adjacent to the sub-basins in high, tilted fault blocks (such as the Rankin Platform trend on the eastern edge of the Exmouth Plateau, and at the Leatherback discovery, offshore North West Cape), and 3) in strata that regionally overlie the sub-basin trend.

Mature and over-mature source rocks of the Locker-Mungaroo/Barrow TPS occur across the entire area (Fig.1). Accumulations are found in 1) tilted fault blocks and sediments overlying tilted fault blocks, of the Exmouth Plateau, 2) structures along the southern and eastern flanks of the sub-basin trend, and 3) on the inner structural terraces adjacent to the stable continent. 
In Province 3948 there are approximately 14 oil and gas fields, 7 gas fields and 10 oil fields with reservoirs in the Neocomian Barrow Group. Jurassic reservoirs account for another 11 fields and other Cretaceous reservoirs an additional 9. The Rankin Platform trend and Exmouth Plateau account for fields containing estimated reserves of 7 billion barrels of oil equivalent (BBOE) (13\% liquids), compared to $1.1 \mathrm{BBOE}$ (45\% liquids) for the sub-basins and $0.9 \mathrm{BBOE}$ (69\% liquids) for the eastern inner strctural terraces (Kopsen, 1994).

Fields and discoveries of the Northwest Shelf are classified in the literature as "pre main-unconformity" or "post main-unconformity" with reference to the hydrocarbon reservoir. The main unconformity, also known as the breakup unconformity (Fig. 3 and 4), was a regional Callovian (Jurassic) event when widespread erosion occured on tilted fault blocks of the high Exmouth Plateau, the rifted and subsiding sub-basins, and the inner structural terraces. This unconformity was the result of a prolonged lowstand of sea level associated with a westward shift of continental rifting and the initiation of sea floor spreading in the Argo Abyssal Plain (Stagg and Colwell, 1994; Barber, 1994).

\section{Pre-main unconformity}

Pre-main unconformity proven reserves are approximately 505 million barrels of oil (MMBO) and 7.5 TCFG and are found primarily in Late Triassic Mungaroo Formation on the Exmouth Plateau/Rankin Platform trend, inner structural terraces and high fault blocks (Delfos and Dedman, 1988). Drilling indicates only the first few fault blocks on the eastern edge of the Rankin Platform trend portion of the Exmouth Plateau have hydrocarbon accumulations. Fault blocks further back into the Plateau have proven to be sub-commercial or dry supporting the theory of hydrocarbon migration out of the 
Jurassic section of the adjacent sub-basins, updip along and under the main unconformity and into Triassic reservoir rocks of the Rankin Platform trend.

There is, however, a gas-condensate discovery that may be important in determining source rock maturity and hydrocarbon migration. North Rankin West field with two wells is located west of the North Rankin field, which is in the first fault block adjacent to the Dampier sub-basin. It is fault separated and downdip of North Rankin field, which produces from Triassic Mungaroo in a tilted fault block under the main unconformity and is sealed by Muderong Shale. The North Rankin West reservoir rocks were deposited in a local graben on the Exmouth Plateau as Jurassic Bathonian age, high energy, nearshore sands. The reservoir is beneath the main unconformity and is sealed by Muderong Shale. A gas column of at least $130 \mathrm{~m}$ has produced at flow rates up to 180 million cubic feet per day (MMCFD) since 1991 and the structure is thought to be filled to spill point (Tilbury, 1994 and Tilbury and Barter, 1992). Unlike other reservoirs of the Rankin Platform trend, this accumulation is not of a configuration or in a position favorable to be filled by hydrocarbons from mature Jurassic Dingo Claystone in the subbasin trend.

Gas-condensate shows and oil shows in pre-main unconformity reservoirs are present on the Exmouth Plateau in Vinck-1, Sirius-1, Investigator-1, Jupiter-1, Zeewulf1, and Resolution-1. Jurassic shales, deposited in individual fault blocks or fault-block trends, are thin and immature or absent and, consequently, these hydrocarbons are sourced by Triassic rocks.

A Rankin Platform trend type fault-block trap was drilled in 1991 offshore of the northern tip of the North West Cape. In this trap, the Leatherback-1 flowed 2332 barrels 
of oil per day (BOPD) from an active oil column of 6 meters overlying a residual oil column of 156 meters in the Mungaroo Formation. This discovery is on the east margin of the Exmouth sub-basin and may be sourced also by Kimmeridgian Upper Dingo Claystone (Bauer and others, 1994).

Post-main unconformity

Proven reserves from post-main unconformity fields are estimated at 1618 MMBO and 41 TCFG, occur across the entire area, and are sourced by both Triassic and Jurassic source rocks. The giant 15 TCFG Scarborough discovery and the $>1$ billion barrels of oil (BBO), 475 billion cubic feet of gas (BCFG) Barrow Island field are examples. Interpreted depositional environments of Jurassic age reservoir rocks include deep-water fan, transgressive marine, and deltaic. The most important post-main unconformity reservoirs are deltaic and deep-water deposits of the Cretaceous Barrow Group. Younger reservoirs have been sourced by migration along faults that breached the regional seal, as in Barrow Island field where the major producing horizon is the Cretaceous Windalia Sandstone Member of the Muderong Shale (Fig. 3).

In the Dingo-Mungaroo/Barrow TPS 394801, oil gravity of post-main unconformity fields ranges from $19^{\circ}-50^{\circ}$ API. In pre-main unconformity fields the gravity range is $36^{\circ}-49^{\circ}$ API. These hydrocarbons are attributed to Jurassic source rocks. Barrow Island field crude is termed "sweet and light" (Miyazaki, 1989). Highly degraded oil and oil above gas relationships are also present (Kopsen and McGann, 1985), indicating multiple episodes of migration.

In Locker-Mungaroo/Barrow TPS 394802, gravity of oil at Rough Range where hydrocarbon source is attributed to pre-Jurassic rock is $34^{\circ}$ API ( Parry and Smith, 1988). 
Hydrocarbons at Rivoli gas field are also attributed to pre-Jurassic source rock with the gravity of the associated oil leg reported to be $19^{\circ}$ API (Lawry and Carter, 1994). Parry and Smith, (1988) interpret the oil at Saladin field, which is measured at $47^{\circ}$ API, to be generated from Triassic source rock. McLerie and others (1991) indicate that oil at Roller, Cowle, and Yammaderry fields is identical to Saladin and from the same source rock. The onshore Tubridgi gas field, which is within fault blocks developed in Triassic rocks during Jurassic subsidence of the Barrow sub-basin, may be sourced by Triassic rocks (Thompson, 1992).

Hydrocarbons are found in reservoirs within, directly overlying, and adjacent to (across faults and unconformities) the Jurassic source rock designated for the DingoMungaroo/Barrow TPS 394801. Migration was generally up-dip and hydrocarbon accumulations remain close to the areal extent of the mature source rock. Fault migration into overlying reservoirs is evident and fault migration through the overlying regional seal is an important method to establish accumulations in post-seal reservoirs. Multiple migration is evidenced by minor to extensive residual hydrocarbon columns, fault spill from one closure to the next one up-dip, spill-point migration to adjacent closures, varying oil-water contacts, and oil over gas relationships.

The Locker-Mungaroo/Barrow TPS 394802, includes fault-fed accumulations overlying mature source rock. Fault reactivation is an important mechanism creating traps and providing remigration paths to post-Triassic accumulations. 


\section{SOURCE ROCK}

The primary petroleum system of Northwest Shelf Province 3948 is the DingoMungaroo/Barrow TPS 394801. This corresponds approximately to the Westralian 2 of Bradshaw and others (1997). A secondary system is the Locker, Mungaroo/Barrow TPS 394802, similar to the Westralian 1 petroleum system of Bradshaw and others (1997). Jurassic Dingo Claystone of the Dingo-Mungaroo/Barrow TPS 394801, is the source rock for hydrocarbons in the sub-basins and on the Rankin Platform trend. Strata of the same age along the Tethyan margin in Europe, the Middle East and Asia are recognized as major source rocks (Klemme and Ulmishek, 1991). Deposition of the Dingo Claystones on the Northwest Shelf occurred mainly in a restricted marine setting as the sub-basins subsided. The Rankin Platform trend edge of the Exmouth Plateau was occasionally exposed, as was most of the Exmouth Plateau. Three major successions of Jurassic Dingo Claystone, lower (Sinemurian/ Pliensbachian), middle (ToarcianBathonian), and upper (Callovian-Kimmeridgian) occupy the sub-basins (Wulff, 1992). The thickest and deepest-water Dingo Claystone intervals were deposited adjacent to the Rankin Platform trend (Wulff, 1992). By Late Kimmeridgian time, the sub-basins were filled and the Dingo Claystone was deposited across most of the Exmouth Plateau. An offshore land area, Argo Land (Bradshaw and others, 1994) and periodic emergence of the Roebuck Basin and the region northeast of the Dampier sub-basin, further restricted circulation. Jurassic deposition in the region northeast of the Dampier sub-basin was dominated by shallow marine and continental coarse clastics so potential hydrocarbon source rocks are terrestrial and localized. 
Total thickness of the Dingo Claystone, estimated from seismic data, is 3-4 km (Stagg and Colwell, 1994). Possible net thickness of the Middle Dingo Formation in the Barrow sub-basin is 100-250 m and Upper Dingo Formation thickness is estimated at up to $1000 \mathrm{~m}$ (Scott, 1994). The Dingo Claystone is thin on the eastern terraced margin and to the north in the Beagle sub-basin where subsidence was not pronounced. Ageequivalent facies to the north are mostly shallow marine and continental sands. On the Exmouth Plateau, Jurassic rocks occur as a thin veneer with pockets up to a few hundred meters in half grabens on the surface (Stagg and Colwell, 1994).

Triassic Locker Shale is considered the source rock for hydrocarbons of LockerMungaroo/Barrow TPS 394802, on the Exmouth Plateau and the North West Cape and may have charged undiscovered reservoirs in the Beagle and Rowley sub-basins and some of the inner structural terraces. The Locker Shale (Gorter, 1994) was deposited in a tectonically quiet sag basin covering all of the Carnarvon Basin and Roebuck Basin. Regional seismic sections show the widespread extent of the entire interval, however, Scott (1994) reports that the source rock varies in quality and is not present in every well. Lowstand erosion and canyon cutting may account for some removal (Gorter, 1994) and Permian topography may account for some nondeposition. There is source rock potential in the continental to marginal marine Triassic Mungaroo, which overlies the entire area (Scott, 1994).

The transgressive Locker Shale was deposited on an angular and erosional unconformity developed on Permian fault blocks and is underlain by a basal transgressive sandstone (Butcher, 1989). The Locker Shale is widespread and represents marine incursion across the entire shelf. This shale and equivalent shales in adjacent areas are 
200-1000 m thick throughout the region. The Triassic Mungaroo Formation overlies the Locker Shale and records a regression beginning in Early Triassic time. The Mungaroo Formation generally coarsens upward and includes interbedded quartzose sandstones, siltstones, shales and coal units. Strata equivalent to the Mungaroo Formation become progressively more marine influenced to the north.

Bradshaw and others (1994) list an average total organic carbon content (TOC) of $>2 \mathrm{wt} \%$ and hydrogen index $(\mathrm{HI})$ of $>150$ from Jurassic marine source rocks with significant terrestrial input. In the Beagle sub-basin, Jurassic TOCs from coals and algal sapropel range from 0.92 to $13.01 \mathrm{wt} \%$ and HIs from 28 to 214 (Blevin and others, 1994). Oil shows in the Nebo-1 discovery may be from Early Jurassic source rocks. Scott (1994) reports TOC of 1-5wt\% and HI from 100-400 for Upper Dingo Claystone, and TOC 0.2-3wt\% and HI 100-250 for Middle Dingo Claystone. Kopsen (1994) discusses Jurassic strata with oil and gas potential in the Barrow and Dampier sub-basins derived from marine shale and coal measures and in the Beagle sub-basin derived from Early Jurassic coal measures.

The oil-and gas-prone Triassic source rocks are generally of moderate quality with local areas of high quality, such as TOCs of $2.5 \mathrm{wt} \%$ and Rock-Eval $\mathrm{S}_{2}$ up to 5 mg/g (Scott, 1994). Two wells, reported by Scott (1994), have the following analysis: TOC wt\%, 0.91 and 0.90; $\mathrm{S}_{2} \mathrm{mg} / \mathrm{g}, 2.58$ and 2.16; HI, 284 and 240; Tmax, $433^{\circ}$ and $429^{\circ}$. These variations may be due in part to locally restricted conditions created when the initial Triassic transgression flooded erosional and tectonically produced relief on the underlying Permian surface. In Candance-1 and Kybra-1 wells, the basal Locker Shale has TOCs of 1.0-2.9wt\% and HI up to 300 (Warris, 1993). Warris (1993) predicts that 
the Locker Shale is mature to over-mature in the Barrow/Dampier sub-basin on the downthrown side of the Flinders Fault. The Triassic strata from the Exmouth sub-basin, Barrow sub-basin, Dampier sub-basin and the Beagle sub-basin is generally rated as a major potential oil source interval by Kopsen (1994). Both marine shale and coal measures are indicated. The Locker Shale in the Exmouth sub-basin and along the eastern and southern margins of the Barrow sub-basin is presently mature (Parry and Smith, 1988).

Subsidence of the sub-basins may have pushed the Locker Shale and coals of the Mungaroo Formation into and through the oil window during the Jurassic Period. These hydrocarbons may still be trapped in deep, untested structures or may have migrated and remigrated escaping to the surface during later lowstand unconformities and tectonic activity. Evidence for mixing of these hydrocarbons with younger hydrocarbons is not conclusive. The Triassic Locker Shale is considered the source of gas-condensate in the Cretaceous reservoir at Scarborough-1 and gas and oil shows in Triassic reservoirs at Vinck, Sirius, Endracht, Jupiter, and Zeewulf on the Exmouth Plateau (Fig. 6b).

The zone of peak hydrocarbon generation (Barber, 1988) is $1 \mathrm{~km}$ thick beginning at approximately $3 \mathrm{~km}$ depth on the Peedamullah shelf in the east where it intersects mostly Permian section. Further west, offshore in the Barrow-Dampier sub-basins, upper Jurassic rocks are currently within the peak oil window (Fig. 5).

The Jurassic Dingo Claystone is thick within the sub-basins and thin on the Exmouth Plateau and is only mature in the area of the sub-basins (Fig. 6a)(Barber, 1988). Accumulations of Dingo-Mungaroo/Barrow TPS 394801 (Fig. 7a), are within the Jurassic sub-basin trend or directly overlying it and in fault blocks along the edges of the 


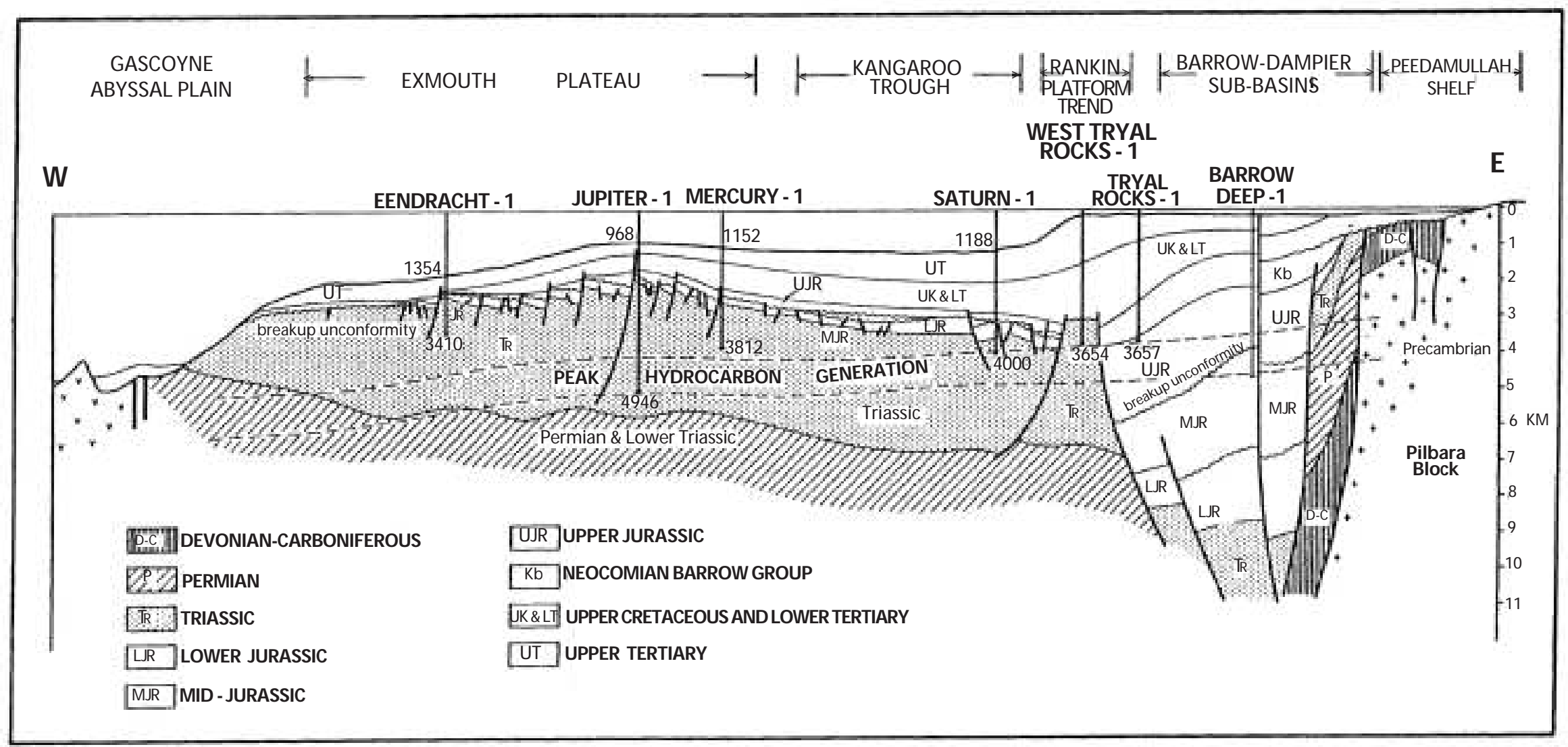

Figure 5. West-East cross section showing sub-basins developed between the Pilbara Block and the Exmouth Plateau. Triassic rocks have been cut off by the formation of the Gascoyne Abyssal Plain. The oil window is shown at 3-4 km depth on the East. Well total depths are in meters. The locationof this cross section is marked on Figure 2. Modified fromBarber, 1988. 

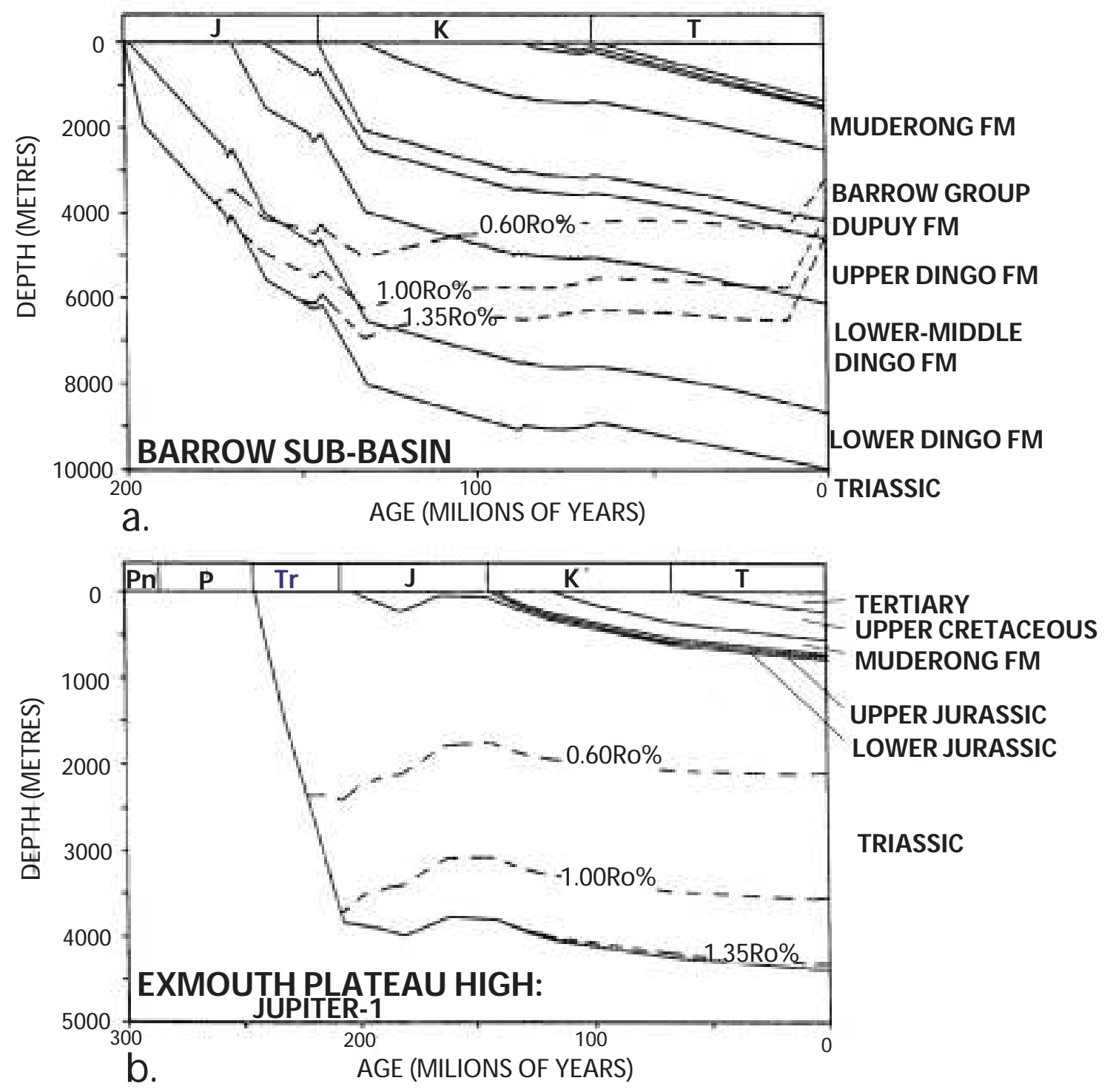

Figure 6. Burial history plots for the Barrow sub-basin(a) and the Exmouth Plateau(b). The zone of maximum hydrocarbon generation is between vitrinite reflectance values of 0.60 Ro\% and 1.00 Ro\%. Modified from Barber, 1988. 


\section{A}

Province Name: NORTHWEST SHELF

TPS Name: DINGO-MUNGAROO/BARROW

Author(s): M.G.BISHOP

Date: $\mathrm{MARCH}, 1998$

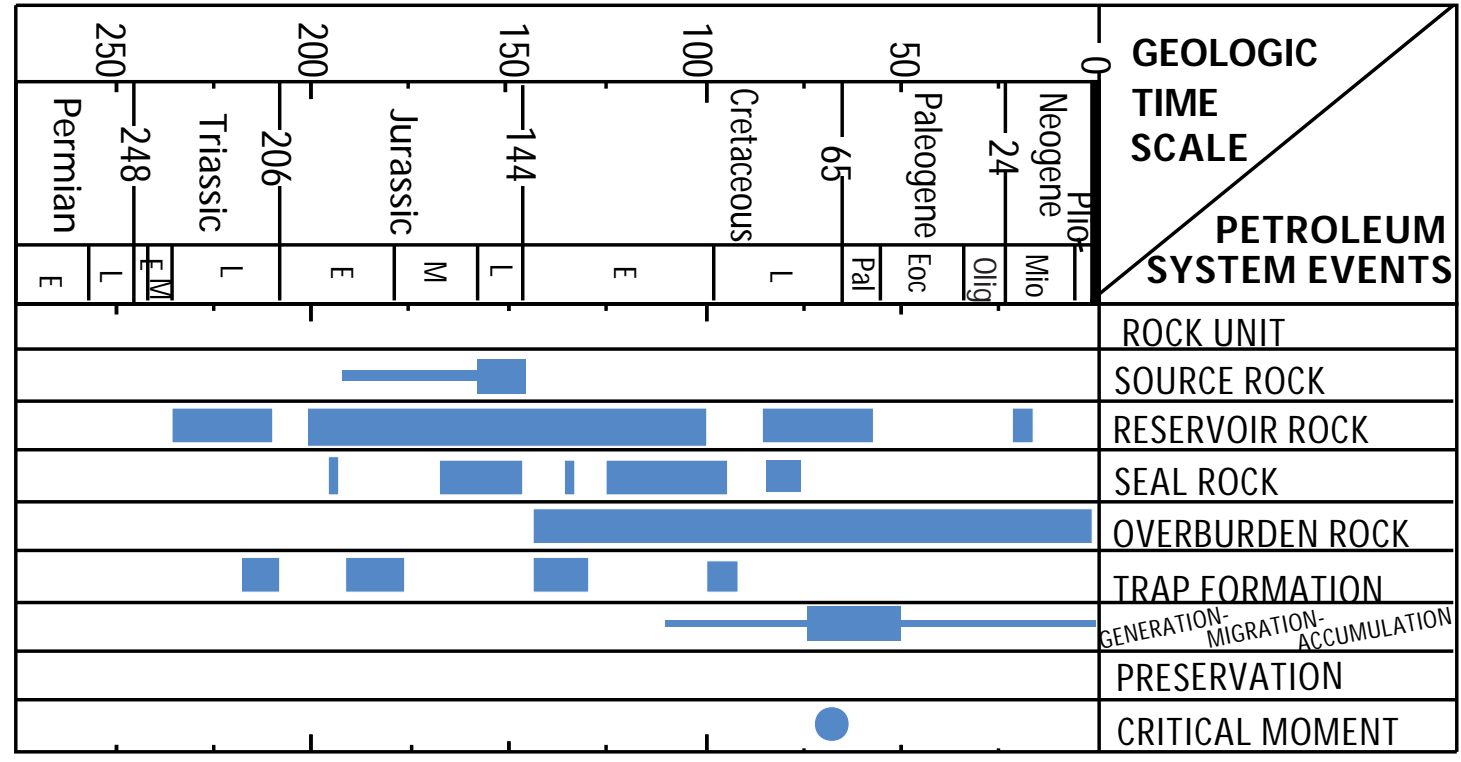

B

Province Name: NORTH WEST SHELF

Author(s) : M. G. BISHOP

TPS Name: L LOCKER-MUNGAROO/BARROW

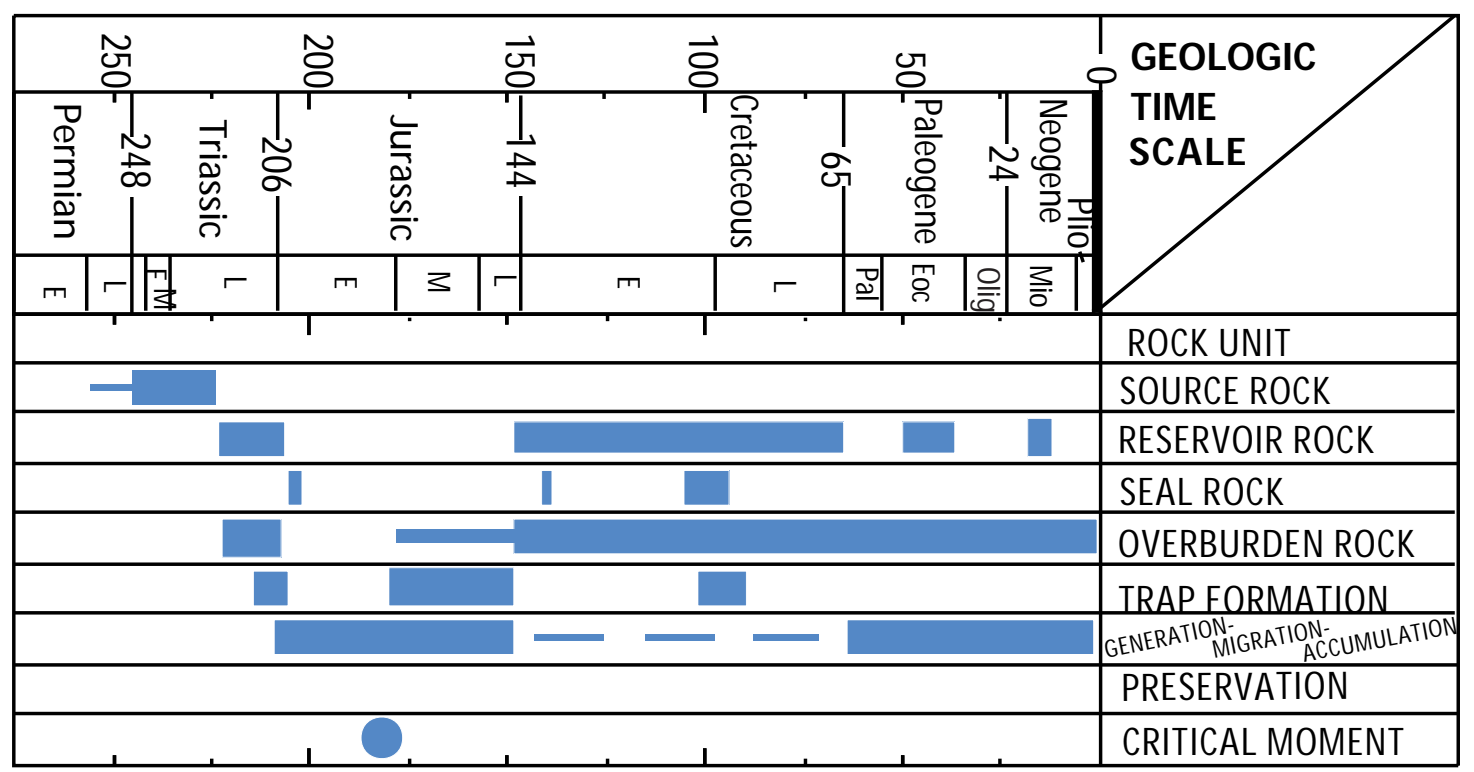

FIGURE 7. Events Charts for the two primary petroleum systems of the Australian Northwest Shelf, A) Dingo source rocks with reservoirs in the Mungaroo and Barrow: B) Locker shale source rocks with reservoirs in the Mungaroo and Barrow. 
sub-basin trend where lateral migration into adjacent sandstone reservoirs could occur (Fig. 5).

Triassic Locker Shale and Mungaroo deltaics of the Locker-Mungaroo/Barrow TPS 394801, underlie all of Province 3948 and thus could be potential source rocks. The Triassic rocks were buried deeply in the sub-basin trend during Jurassic subsidence and would have become over-mature in the area at that time (Fig.4 and Fig. 6). In the Exmouth Plateau region the same potential section has thin Jurassic, Cretaceous and Cenozoic overburden (Fig. 5). The Triassic source rocks under the Exmouth Plateau entered the oil window in Late Triassic time and these rocks have remained within the oil window (Fig. 6b). The Triassic interval in this location is interpreted as the source for overlying shows and discoveries (Fig. 7b).

\section{OVERBURDEN ROCK}

During the Cretaceous Period, open marine and progressively deep-water conditions began to prevail. The Northwest Shelf was the site of Cretaceous and Tertiary shelf progradation across the inner sub-basins and thin deposition across the outer plateaus (AGSO North West Shelf Study Group, 1994). The modern shelf edge lies roughly over the Rankin Platform trend but shifts northwest in the Roebuck Basin area (AGSO North West Shelf Study Group, 1994).

As the supply of clastic sediment decreased during Cretaceous and Tertiary time and the Northwest Shelf portion of the Australian tectonic plate drifted to tropical latitudes, deposition of radiolarite, marl, calcilutite, calcarenite, siltstones, and limestones dominated and continues into the present (Fig. 3). The Cenozoic carbonate shelf is up to 
$3 \mathrm{~km}$ thick offshore (Stagg and Colwell, 1994). The carbonate sequence records small unconformities related to sea level fluctuations (Stagg and Colwell, 1994) and a period of minor tectonic activity. Burial history analysis (Barber, 1988) indicates steady subsidence since Cretaceous time and the generally different histories of the plateau and the sub-basin trend (Fig. 6a and b).

Overburden for the Lower Dingo Claystone consisted of Jurassic shales and sandstones in the subsiding sub-basins. The oldest Dingo Claystones may have been within the oil window while the younger strata were being deposited. Post-Jurassic overburden includes sandstones of the Cretaceous delta over the Exmouth and Barrow sub-basins and shale over the Dampier and Beagle sub-basins. Post-Neocomian deposition involved the establishment of a carbonate shelf. The current shelf edge lies over the Rankin Platform trend.

Triassic source rocks experienced little overburden on the Exmouth Plateau during the Jurassic Period but have shared a thinner section of post Neocomian clastic and carbonate deposits. The Triassic was buried deeply and quickly during Jurassic faulting and subsidence of the Barrow and Dampier sub-basin trend. At the southern and eastern edges of the Exmouth and Barrow sub-basins the Triassic was buried less deeply.

\section{TRAP STYLE}

Fault-enhanced three-way dip, four-way closure as a result of stratigraphic depositional relief combined with differential compaction, and drape of fault blocks are common traps in the Barrow, Dampier, and Exmouth sub-basins. Barrow Island field is a highly faulted, drape anticline. Harriet, South Pepper, North Herald, Chervil, Saladin, 
Yammaderry, Cowle among other discoveries are examples of traps formed where downthrown Muderong and Gearle shales (Winning Group) seal the upthrown Barrow Group and Birdrong sands (Parry and Smith, 1988). Some stratigraphic traps are combined with structure and are draped in structurally high positions on fault-block trends.

Trap style on the Rankin Platform trend involves tilted fault blocks sealed by an erosional unconformity and overlying Muderong Shale. Hydrocarbon accumulations are found in stacked sands of the Mungaroo Formation. Some stacked reservoirs share a down-dip oil/water contact in a fault block. According to Stein and Scott (1993), "The Rankin Platform is one of the most prolific hydrocarbon provinces in the Australasian region, with discovered recoverable reserves estimated to be in excess of $25 \mathrm{TCF}$ of gas, 700 MMBBL of condensate and 200 MMBBL of oil.”.

Trap style on the Exmouth Plateau is the same as that of the Rankin Platform trend, tilted fault blocks of Triassic Mungaroo reservoir rocks. Traps over the Exmouth Plateau in Barrow Group reservoirs are structural highs due to post-Neocomian reactivation of post-Triassic faults. Onshore and on the inner structural terraces, trap style includes the faulted anticlines of Rough Range and Rivoli fields (Lawry and Carter, 1992), and fault traps of Turbidgi field (Thompson, 1992).

By far, the most important reservoir of Province 3948 Northwest Shelf is the Barrow Group, which accounts for estimated recoverable reserves of more that 400 MMBO, 4 TCFG, and 108 million barrels of condensate (MMBC) in the DingoMungaroo/Barrow 394801 petroleum system. More than 35 MMBO, 44 TCFG, and 836 MMBC are assigned to the Mungaroo Formation. 
Major traps were formed by post-Triassic faulting. Reactivation of these faults and post-Cretaceous basin inversion, particularly on the Exmouth Plateau, allowed migration into overlying sediments. The Roebuck Basin may have been more stable after initial post- Triassic tectonics (Stagg and Colwell, 1994).

Stratigraphic traps formed by depositional and compactional relief, combined with fault-block drapes with occasional minor faulting, and tilted fault blocks comprise the major trap types in Triassic, Jurassic, and Cretaceous reservoirs. Much remigration has occurred due to reactivation of faults and spilling from over-filled structures.

\section{RESERVOIR ROCK}

More than 12 groups or formations have been tested and proven to be hydrocarbon reservoirs. These intervals have not been drilled in some deeper water settings or below current well depths in the sub-basin trend. Additional stratigraphic traps and structural targets have not been tested.

The Triassic Mungaroo Formation is a major reservoir in fault blocks tilted by post-Triassic tectonics (Fig. 5). The Ladinian to Rhaetian age Mungaroo Formation consists of fluvial, deltaic, and alluvial sediments prograding from the continent, in a modern northwest direction, across the inner structural terraces, across what would become the sub-basin trend, and grading into prodelta marine sediments toward the far edge of the Exmouth Plateau (Barber, 1988).

Jurassic deltaic, alluvial, and deep-water siliciclastic deposits shed from the stable continent were deposited in the subsiding sub-basin trend. These clastic intervals are also important producing reservoirs. 
The Neocomian Barrow Group delta prograded northeastward across the Exmouth Plateau and into the Barrow sub-basin. The northern limits of topsets of the Barrow Group reach from Vinck-1 east to Investigator-1 wells and across to Gorgon field and the northern end of Barrow Island (Barber, 1988), roughly perpendicular to the modern coast (Fig. 2). Clastics, shed from the Indian plate, accumulated until the plate separated and drifted north, cutting off sediment supply in the Hauterivian Stage.

The Barrow Group delta prograded into a deep-water basin and onlapped the Jurassic Dupuy Formation wedge in shallower water against the craton . Maximum thickness of the Barrow Group is about $2 \mathrm{~km}$, and it thins to $1.2 \mathrm{~km}$ at the northern limits (Stagg and Colwell, 1994). The Barrow Group consists of three major formations: the lower Malouet Formation, deltaic bottomsets and submarine fans of PortlandianBerriasian age; the Flacourt Formation, deltaic topsets and foreset shales of BerriasianValanginian age; and the Flag Sandstone, deep-water, lowstand fans of Valanginian age. (Eriyagama and others 1988).

Shaly foresets and sandy topsets are present from Saladin field to Cowle field but only sandy topsets are present at Roller field. Barrow reservoirs at Saladin, Yammaderry and Cowle are fluvial channel sandstones (lower sandstones) overlain by tidal backbarrier sandstones (bioturbated and upper sandstones). Roller field reservoir is fluvial lower sandstones only. Upper sandstones of the Barrow at Saladin, Yammaderry and Cowle represent an early marine transgression drowning the Barrow delta following continental separation south of the Exmouth Plateau (McLerie and others, 1991).

The Barrow Group Flag Sandstone produces oil in the Harriet field and accounts for discoveries in Orpheus-1, Plato-1, and Campbell-2 wells. A study by de Boer and 
Collins (1988) indicates that the Flag Sandstone consists of quartzitic sands reworked into deep-water fans from Barrow delta distributary rivers and transported down the Lowendal Syncline. Four-way closures, due to relief on the top of the Flag fans, are sufficient to trap hydrocarbons at Bambra, Campbell, Rosette, and Harriet fields. Some faulting may help confine these accumulations (McClure and others, 1988). There is an erosional southwest limit just south of Barrow Island, an erosional southeast limit east of Barrow Island, a northwest limit west of Tryal Rocks- 1 and a northern shaleout south of Withnell-1. The Flag Sandstone is one of several identified or inferred deep-water fans deposited generally to the north into the basin in front of the Barrow delta. Another of these fans is the reservoir at Scarborough-1 on the Exmouth Plateau.

The Birdrong Sandstone from the onshore Carnarvon Basin is described as a transgressive basal deposit and ranges in age from late Valanginian or early Hauterivian to Barremian and Aptian. It produces gas at Tubridgi and Rivoli fields, oil at Rough Range field and oil and gas at Wandoo field. Mapped isopach thicks occur at Sholl Island-1, Direction-1 Hope Island-1, Whitlock Dam-1, and Resolution-1 (Hocking, 1988). The Birdrong Sandstone, which may be equivalent to the Mardie Greensand, generally overlies the Mardie Greensand where it is present and lies parallel to the present coast and north of North West Cape.

The transgressive Mardie Greensand of the Muderong Shale was deposited unconformably over fluvial or back-barrier Barrow Group after a time gap of several million years (McLerie and others, 1991). The Mardie Greensand may be the younger and northern equivalent of the Birdrong Sandstone, but sometimes it is placed at the top of the Barrow Group under the Hauterivian unconformity. Since the Mardie Greensand 
is distinct, it may be the lateral equivalent to the Birdrong Sandstone in a slightly differing depositional environment that promoted glauconite development and preservation. The Mardi Greensand represents a deeper-water depositional setting that the Birdrong Sandstone (Hocking and others, 1988) and was deposited over about 15 million years. It is a gas bearing reservoir on the Peedamullah shelf in Mardi-1 and an oil and gas bearing reservoir in Pepper South and Barrow Island fields. It oversteps the Barrow Group to lie on locally present conglomerates on the southeastern parts of the Peedamullah shelf. The Mardie Greensand ranges in thickness from 15-30 m with a maximum thickness of $59 \mathrm{~m}$ at Rosily-1A. It pinches out on the northernmost foreset of the Barrow delta and grades into shale. Mapped thicks occur to the southwest of Barrow Island, offshore Exmouth and north of North West Cape (Hocking, 1988).

Oil is present in Aptian age, marine Mardie Greensand on Barrow Island. Suggestions of the lateral equivalence of the Birdrong Sandstone and Mardie Greensand come from two wells where the two sands occur at the same stratigraphic level. The Mardie Greensand appears to be of deeper-water, sub-littoral origin and interfingers with the Birdrong Sandstone at other locations.

The Aptian Windalia Sandstone member of the Muderong Shale and is interpreted to have originated as a storm-generated, shelf-sand deposited below fair-weather wave base. It is the main hydrocarbon reservoir in the Barrow Island oil field.

In the Dampier sub-basin (Howell, 1988), reservoirs that are hydrocarbon sourced and locally sealed by the Dingo Claystone are present in transgressive sands, regressive deltas (the Bathonian Legendre Formation), and deep-water fans. Other reservoir rocks are found in the Tithonian Dupuy Member of the Upper Dingo Claystone and the deep- 
water fan Angel Sandstone of the Dupuy Member, which produces at Wanea, Cossack, and Angel fields. The Dupuy submarine fan built into the Barrow sub-basin from the east and southeast across the Dingo Claystone.

The Late Jurassic Angel Sandstone of the northern Barrow-Dampier sub-basin and its equivalent, the Dupuy Member of the Upper Dingo Claystone in the Barrow Island area, are both characterized as deep-water turbidites (Bint, 1991).

Facies of the Triassic Mungaroo Formation include meandering and braided stream, prodelta, distributary mouth bar, distributary/fluvial channel and levee, interdistributary bay, crevasse splay, and coal-swamp deposits (Barber, 1988). The Mungaroo Formation is approximately $3000 \mathrm{~m}$ thick and displays three main stacked deltaic sequences capped by alluvial plain deposits within which are several highfrequency sequences (Barber, 1988). This interval contains reservoirs on tectonically high fault blocks on the Exmouth Plateau, Rankin Platform trend, and areas of the eastern edges of the sub-basin trend and the inner structural terraces. Within the sub-basin trend the interval has not been reached by the drill and is not readily imaged by seismic data.

Overall, porosity and permeability are good in all reservoir facies. Primary porosity is largely preserved and secondary porosity can be a contributing factor. Nonmarine sandstones of the Mungaroo Formation have porosity averaging $28 \%$ with highs of $34 \%$ in $30 \mathrm{~m}$ thick delta plain units (Barber, 1988). Permeability can be as high as $1000 \mathrm{mD}$. Burial depth decreases these values and carbonate cementation in the marine intervals affects both porosity and permeability. 
Jurassic and Cretaceous reservoirs range in porosity from $16 \%$ to $35 \%$ and permeability from $27 \mathrm{mD}$ to $3000 \mathrm{mD}$. Minor quartz overgrowths, authigenic clay and feldspar dissolution are reported.

\section{SEAL ROCK}

The Muderong Shale is the regional seal deposited across the Northwest Shelf as a result of a major transgression in late Valanginian (Fig. 3). It is approximately $900 \mathrm{~m}$ thick and interfingers with the distal basinal deposits of the Barrow Group and onlaps the top of the succession. Maximum transgression occurred in the Aptian Stage after a slow reworking of the top of the Barrow delta into the Birdrong Sandstone and Mardie Greensand. The Muderong Shale and its sandy members span the Cretaceous Berriasian to Aptian Stages and are overlain by a widespread unconformity (Butcher, 1989).

\section{UNDISCOVERED PETROLEUM BY ASSESSMENT UNIT}

In the Northwest Shelf Province 3948, the primary petroleum system, DingoMungaroo/Barrow TPS 394801, includes one assessment unit, 39480101 (Fig. 1). This assessment unit consists of the sub-basins and the Rankin Platform (Fig. 2). Deep-water fans of Jurassic and Cretaceous age have been successful exploration targets and will continue to be located and tested. Rankin-type traps consisting of tilted fault blocks of Mungaroo Formation are targets in other locations. A recent discovery at Leatherback-1 tested this type of trap along the southern margin of the sub-basin trend. Growth-fault traps associated with formation of the sub-basin trend and the shelf-edge next to the inner structural terrace margin and other sub-basin margins are potential targets. Minor 
carbonate intervals found within the Jurassic section might be targeted on structural highs or in depositional mound situations. Repeated episodes of regional or eustatic sealevel low-stands produced lowstand erosional valleys that have been identified. These lowstand valley-fill intervals have not been exploration targets, although this type of geological setting has been a successful target in other places in the world. Even Tertiary reservoirs are potential targets as indicated by the Maitland gas discovery, which targeted a seismic HCI (hydrocarbon indicator) (Sit, 1994).

The secondary petroleum system, Locker-Mungaroo/Barrow TPS 394802, includes one assessment unit, 39480201 (Fig. 1). This assessment unit consists of the Exmouth Plateau, the southern and northern portions of the province and a narrow area along the eastern margin of the province. There are many untested tilted fault blocks of Mungaroo Formation remaining in the Exmouth Plateau area. Oil and gas shows in some of these blocks indicate potential discoveries. Targeting tilted fault blocks of Mungaroo Formation on the edges of the Kangaroo trough or other tectonic basins on the Exmouth Plateau may prove successful. Clastic reservoirs formed within basins or fault-block lows on the Exmouth Plateau and sealed by the main unconformity and overlying Muderong Shale might produce reserves like those of North Rankin West field. Basins inverted due to tectonic reactivation of Triassic faults, particularly on the Exmouth Plateau, are seen on seismic data in the Cretaceous section overlying the Exmouth Plateau at Investigator-1. These obvious and more subtle inversions have not yet been well explored.

Exploration continues on the Northwest Shelf with numerous discoveries in the last few years adding significant reserves. Future prospects are numerous and include 
proven targets in additional locations and greater water depths and new targets yet to be proven.

\section{REFERENCES}

AGSO North West Shelf Study Group, 1994, Deep reflections on the North West Shelf: changing perceptions of basin formation, in Purcell, P. G., and Purcell, R. R., eds., The Sedimentary Basins of Western Australia: Proceedings of Petroleum Exploration Society of Australia Symposium, Perth, 1994, p. 63-76.

Baillie, P. W., Powell, C. McA., Li, Z. X., and Ryall, A. M., 1994, Tectonic framework of Western Australia's neoProterozoic to Recent sedimentary basins, in Purcell, P. G., and Purcell, R. R., eds., The Sedimentary Basins of Western Australia: Proceedings of Petroleum Exploration Society of Australia Symposium, Perth, 1994, p. 45-62.

Barber, P. M., 1988, The Exmouth Plateau deep water frontier: a case history, in Purcell, P. G., and Purcell, R. R., eds., The North West Shelf, Australia: Proceedings of Petroleum Exploration Society Australia Symposium, Perth, 1988, p. 173-188.

Barber, P. M., 1994, Sequence stratigraphy and petroleum potential of Upper Jurassic Lower Cretaceous depositional systems in the Dampier sub-basin, North West Shelf, Australia, in Purcell, P. G., and Purcell, R. R., eds., The Sedimentary 
Basins of Western Australia: Proceedings of Petroleum Exploration Society of Australia Symposium, Perth, 1994, p. 525-542.

Bauer, J. A., Hooper, E. C. D., and Crowley, J., 1994, The Leatherback discovery, Carnarvon Basin, in Purcell, P. G., and Purcell, R. R., eds., The Sedimentary Basins of Western Australia: Proceedings of Petroleum Exploration Society of Australia Symposium, Perth, 1994, p. 573-582.

Bentley, J., 1988, The Candace Terrace - a geological perspective, in Purcell, P. G., and Purcell, R. R., eds., The North West Shelf, Australia: Proceedings of Petroleum Exploration Society Australia Symposium, Perth, 1988, p. 157-188.

Bint, A. N., 1991, Discovery of the Wanaea and Cossack oil fields: APEA Journal, Volume 31, Part 1, p. 22-31.

Blevin, J. E., Stephenson, A. E., and West, B. G., 1994, Mesozoic structural development of the Beagle sub-basin - implications for the petroleum potential of the northern Carnarvon basin, in Purcell, P. G., and Purcell, R. R., eds., The Sedimentary Basins of Western Australia: Proceedings of Petroleum Exploration Society of Australia Symposium, Perth, 1994, p. 479-496.

Bradshaw, M. T., Bradshaw, J., Murray, A. P., Needham, D. J., Spencer, L., Summons, R. E., Wilmot, J., and Winn, S., 1994, Petroleum systems in west Australian 
basins, in Purcell, P. G., and Purcell, R. R., eds., The Sedimentary Basins of Western Australia: Proceedings of Petroleum Exploration Society of Australia Symposium, Perth, 1994, p. 93-118.

Bradshaw, M. T., Edwards, D., Bradshaw, J., Foster, C., Loutit, T., McConachie, B., Moore, A., Murray, A., and Summons, R., 1997, Australian and eastern Indonesian petroleum systems: Indonesian Petroleum Association Proceedings of the Petroleum Systems of SE Asia and Australasia Conference, May 1997, p. 141153.

Bradshaw, M. T., Yeates, A. N., Beynon, R. M., Brakel, A. T., Langford, R. P., Totterdell, J. M., and Yeung, M., 1988, Palaeogeographic evolution of the North West Shelf region, in Purcell, P. G., and Purcell, R. R., eds., The North West Shelf, Australia: Proceedings of Petroleum Exploration Society Australia Symposium, Perth, 1988, p. 29-54.

Butcher, B. P., 1989, Northwest shelf of Australia, in Edwards, J. D., and Santogrossi, P. A., eds., Divergent/Passive Margin Basins: American Association of Petroleum Geologists memoir 48, p. 81-115.

de Boer, R., and Collins, L. B., 1988, Petrology and diagenesis of the Flag Sandstone, Harriet Field, Barrow sub-basin, in Purcell, P. G., and Purcell, R. R., eds., The 
North West Shelf, Australia: Proceedings of Petroleum Exploration Society Australia Symposium, Perth, 1988, p. 225-236.

Delfos, E., and Dedman, R., 1988, The petroleum potential of the Peedamullah Shelf, in Purcell, P. G., and Purcell, R. R., eds., The North West Shelf, Australia: Proceedings of Petroleum Exploration Society Australia Symposium, Perth, 1988, p. $147-156$.

Eriyagama, S. C., Collins, L. B., and Hocking, R. M., 1988, Depositional framework and major lithostragraphic variations of the Barrow Group, in Purcell, P. G., and Purcell, R. R., eds., The North West Shelf, Australia: Proceedings of Petroleum Exploration Society Australia Symposium, Perth, 1988, p. 189-202.

Exon, N. F., and von Rad, U., 1994, The Mesozoic and Cainozoic sequences of the Northwest Australian margin, as revealed by ODP core drilling and related studies, in Purcell, P. G., and Purcell, R. R., eds., The Sedimentary Basins of Western Australia: Proceedings of Petroleum Exploration Society of Australia Symposium, Perth, 1994, p. 181-200.

Gorter, J. D., 1994, Triassic sequence stratigraphy of the Carnarvon Basin, Western Australia: in Purcell, P. G., and Purcell, R. R., eds., The Sedimentary Basins of Western Australia: Proceedings of Petroleum Exploration Society of Australia Symposium, Perth, 1994, p. 397-413. 
Hocking, R. M., 1988, Regional geology of the Northern Carnarvon Basin, in Purcell, P. G., and Purcell, R. R., eds., The North West Shelf, Australia: Proceedings of Petroleum Exploration Society Australia Symposium, Perth, 1988, p. 97-114.

Hocking, R. M., Voon, J. W. K., and Collins, L. B., 1988, Stratigraphy and sedimentology of the Basal Winning Group, Northern Carnarvon Basin, in Purcell, P. G., and Purcell, R. R., eds., The North West Shelf, Australia: Proceedings of Petroleum Exploration Society Australia Symposium, Perth, 1988, p. 203-224.

Howell, E. A., 1988, The Harriet oilfield, in Purcell, P. G., and Purcell, R. R., eds., The North West Shelf, Australia: Proceedings of Petroleum Exploration Society Australia Symposium, Perth, 1988, p. 391-402.

Klemme, H. D. and Ulmishek, G. F., 1991, Effective petroleum source rocks of the world: stratigraphic distribution and controlling depositional factors: American Association of Petroleum Geologists Bulletin v. 75, no. 12, p. 1809-1851.

Kopsen, E., 1994, Northern Carnarvon Basin hydrocarbon distribution and future petroleum potential, in Purcell, P. G. and Purcell, R. R., eds., The Sedimentary Basins of Western Australia: Proceedings of Petroleum Exploration Society of Australia Symposium, Perth, 1994, p. 127-140. 
Kopsen, E., and McGann, G., 1985, A review of the hydrocarbon habitat of the eastern and central Barrow-Dampier sub-basin, Western Australia: The APEA Journal, Volume 25, p. 154-176.

Lawry, P. J., and Carter, P. A., 1992, Rivoli-1 gas discovery - Exmouth sub-basin, western Australia, APEA Journal, Volume 32, Part 1, p.94-102.

Lawry, P. J., and Carter, P. A., 1994, The Rivoli gas field, Exmouth sub-basin, in Purcell, P. G., and Purcell, R. R., eds., The Sedimentary Basins of Western Australia: Proceedings of Petroleum Exploration Society of Australia Symposium, Perth, 1994, p. 649-652.

Loutit, T. S., Summons, R. E., Bradshaw, M. T., and Bradshaw, J., 1996, Petroleum systems of the North West Shelf, Australia: how many are there?: Proceedings, Indonesian Petroleum Association Twenty-fifth Silver Anniversary Convention, October, 1996, p. 437-452.

McClure, I. M., Smith, D. N., Williams, A. F. , Clegg, L. J., and Ford, C. C., 1988, Oil and gas fields in the Barrow sub-basin, in Purcell, P. G., and Purcell, R. R., eds., The North West Shelf, Australia: Proceedings of Petroleum Exploration Society Australia Symposium, Perth, 1988, p. 371-390. 
McLerie, M. K., Tait, A. M., and Sayers, M. J., 1991, The Yammaderry, Cowle and Roller discoveries in the Barrow sub-basin, Western Australia: APEA Journal, Volume 31, Part 1, p. 32-41.

Miyazaki, S., 1989, Characterization of Australia's oil fields by fluid and reservoir properties and conditions: APEA Journal, V. 29, Part 1, p. 287-298.

Parry, J. C., and Smith, D. N., 1988, The Barrow and Exmouth sub-basins, in Purcell, P. G., and Purcell, R. R., eds., The North West Shelf, Australia: Proceedings of Petroleum Exploration Society Australia Symposium, Perth, 1988, p. 129-146.

Petroconsultants, 1996, Petroleum exploration and production database: Houston, Texas, Petroconsultants, Inc., (data base available from Petroconsultants, Inc., P. O. Box 740619, Houston, TX, 77242-0619).

Purcell, P. G., and Purcell, R. R., 1988, The North West Shelf, Australia - an introduction, in Purcell, P. G., and Purcell, R. R., eds., The North West Shelf, Australia: Proceedings of Petroleum Exploration Society Australia Symposium, Perth, 1988, p. 3-16.

Ross, M. I., and Vail, P. R., 1994, Sequence stratigraphy of the Lower Neocomian Barrow delta, Exmouth Plateau, northwestern Australia, in Purcell, P. G., and Purcell, R. R., eds., The Sedimentary Basins of Western Australia: Proceedings 
of Petroleum Exploration Society of Australia Symposium, Perth, 1994, p. 435448.

Scott, J., 1994, Source rocks of west Australian basins-distribution, character and models, in Purcell, P. G., and Purcell, R. R., eds., The Sedimentary Basins of Western Australia: Proceedings of Petroleum Exploration Society of Australia Symposium, Perth, 1994, p. 141-158.

Sit, K. H., Hillock, P. M., and Miller, N. W. D., 1994, Maitland gas discovery - a geological/geophysical case history, in Purcell, P. G., and Purcell, R. R., eds., The Sedimentary Basins of Western Australia: Proceedings of Petroleum Exploration Society of Australia Symposium, Perth, 1994, p. 597-614.

Stagg, M. J., and Colwell, J. B., 1994 The structural foundations of the northern Carnarvon Basin, in Purcell, P. G., and Purcell, R. R., eds., The Sedimentary Basins of Western Australia: Proceedings of Petroleum Exploration Society of Australia Symposium, Perth, 1994, p. 349-364.

Stein, A., and Scott, J., 1993, Elephant hunting on the Rankin Platform: PESA News (The National Newsletter of the Petroleum Exploration Society of Australia), August/September, 1993, p 21-24. 
Thompson, M., 1992, The development geology of the Tubridgi gas field: APEA Journal, Volume 32, Part 1, p. 44-55.

Tilbury, L., 1994, Recent gas discoveries on the Rankin Trend, North West Shelf, Australia: the Echo/Yodel and North Rankin West fields, in Purcell, P. G., and Purcell, R. R., eds., The Sedimentary Basins of Western Australia: Proceedings of Petroleum Exploration Society of Australia Symposium, Perth, 1994, p. 633638.

Tilbury, L., and Barter, T., 1992, New technology - a major impact on a producing field: North Rankin gas field, north west shelf, Australia: APEA Journal, Volume 32, Part 1, p. 20-32.

Veevers, J. J., 1974, Western continental margin of Australia, in Burk, C. A., and Drake C. L., eds., The Geology of Continental Margins: Springer-Verlag, p.605-616.

Warris, B. J., 1993, The hydrocarbon potential of the Palaeozoic basin of Western Australia: APEA Journal, Volume 33, Part 1, p. 123-137.

Whibley, M., and Jacobson, T., 1990, Exploration in the northern Bonaparte basin, Timor Sea - WA-199-P: APEA Journal, Volume 30, Part 1, p. 7-25. 
Wulff, K., 1992, Depositional history and facies analysis of the upper Jurassic sediments in the eastern Barrow sub-basin: APEA Journal, Volume 32, Part 1, p. 104-122. 